\title{
Mapping of flow paths in large, anastomosing arid zone rivers: Cooper Creek, Australia
}

\author{
$\underline{\text { A. Mohammadi }}^{\text {a }}$, D. Ryu ${ }^{\text {a }}$ and J.F. Costelloe ${ }^{\text {a }}$ \\ ${ }^{a}$ Department of Infrastructure Engineering, University of Melbourne \\ Email: abbasm@student.unimelb.edu.au
}

\begin{abstract}
Anastomosing rivers have moderately to highly sinuous, multiple, interconnected channels which form in low gradient floodplains and there are numerous examples of them in the world, such as rivers in inland Australia. Arid anastomosing rivers of Australia experience high transmission losses during floods and mapping of channels and inundation area can play an important role in quantifying the water lost via evaporation, infiltration or impoundment in wetlands. In this article, two DEM-based stream definition methods and a zero dimensional model were used to map channel patterns in Cooper Creek, Australia. The D8 and D-infinity DEM-based stream definition methods replicate a dendritic structure for the channel map of Cooper Creek which is in contradiction to its anastomosing pattern. In addition, a zero dimensional model in which a hypothetical water surface is overlain to the DEM was run in a large reach of Cooper Creek. The model cannot generate flow patterns along the length of the reach or else inundates a major part of the floodplain and does not illustrate the anastomosing patterns. It is found that the effect of scale, inability of model to calculate realistic water level dropping with flow, DEM inaccuracy and its limitation to capture micro topography are important in accurate mapping of inundation area by zero dimensional models and the model is not suitable for long river reaches. Results suggest that hydrodynamic models, informed by optical remote sensing data and satellite altimetry data, may be the most useful method to simulate and validate the flow routes and inundation area for anastomosing rivers of arid floodplains with high transmission losses.
\end{abstract}
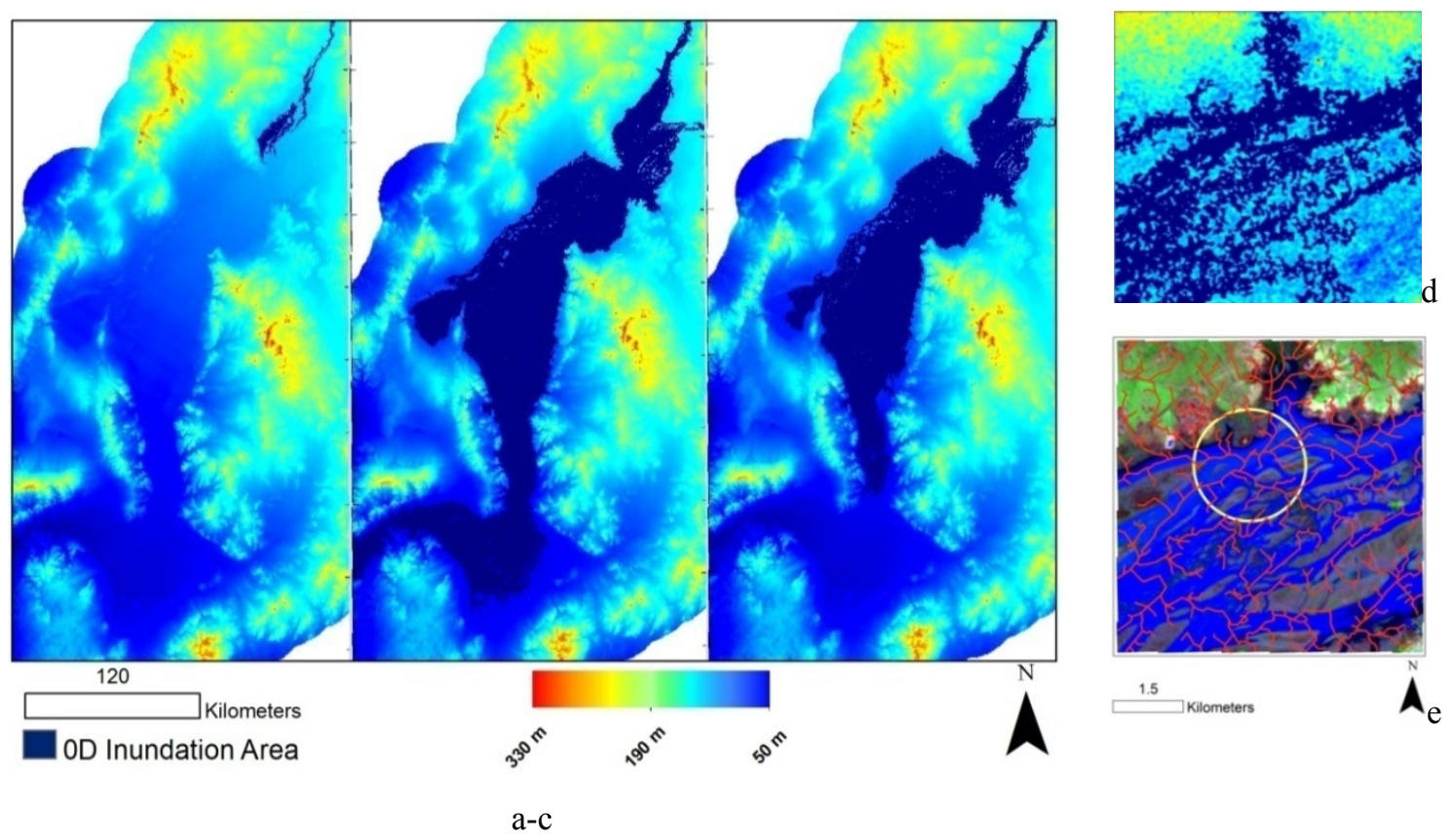

Figure (a) Flood mapping of Cooper Creek (dark blue) for a small flood with no transmission loss; (b) Medium flood with no transmission loss; (c) Medium flood with 75\% reduction of water depth as transmission loss; (d) Inundation map of a small region in Thompson River downstream of Longreach $(6.75 * 6.75 \mathrm{~km})$ modelled by 0 -D model (dark blue); (e) Observed coverage for the 1990 flood event, image of Landsat 5 TM (bands 2 (Red), 4 (Green), and 7 (Blue)) and overlaying TAUDEM stream network with only one replication of bifurcation in anastomosing rivers (center of yellow circle).

Keywords: Anastomosing Rivers, Mapping, ArcHydro, TAUDEM, Cooper Creek 


\section{INTRODUCTION}

Anastomosing rivers form on low gradients and are characterised by moderately to highly sinuous, multiple, interconnected channels separated by stable (and mostly) vegetated floodplains (Schumann, 1989). Anastomosing rivers can be found in different climates, including arid and semi-arid regions of the world, such as the upper Darling River, Cooper Creek and Fitzroy River in Australia, Middle Niger and Okavango rivers in Africa and Red Creek in the United States (Makaske, 2001).

One of the main water resources issues for these rivers is estimating transmission losses resulting from the decrease in discharge in the arid lower reaches (Knighton and Nanson, 1997). The dominant processes of water loss in the floodplains are infiltration, evapotranspiration and ponding of water in natural depressions (Knighton and Nanson, 1994). In arid zone, anastomosing rivers, where the width of floodplains can be in the order of tens of kilometres, the transmission loss and travel time of flow events are sensitive to the flow paths taken across the complex floodplain. All of the mentioned factors of transmission loss are sensitive to the areal extent of inundation for a given flood size (McMahon et al., 2008). Knighton and Nanson (1994) show that in Cooper Creek of the Lake Eyre Basin (LEB), the effect of seasonality and antecedent conditions on the transmission loss is small but the movement of water, through primary channels or floodplain channels can play a significant role in the transmission loss and travel time of flooding water. Therefore, explicit representation of routing and spatial distribution of flooding is highly important to estimate transmission losses in anastomosing rivers (Costelloe et al., 2003).

The spatial distribution of flooding is predominantly determined by surface elevation. The Shuttle Radar Topographic Mission (SRTM) digital elevation model (DEM) for Australia, released in 2005 with a resolution of 3 arc second $(\sim 90 \mathrm{~m})$, and the subsequent processing of data by CSIRO and release of 1 arc second $(\sim 30 \mathrm{~m})$ hydrological DEM in 2009-2011, are important sources of high-resolution DEM for the entire continent. These datasets can be used to quantify hydrological processes with higher accuracies in Australia (Dowling et al., 2011) and provide the potential for advancing our capacity to model complex anastomosing river systems, such as the major rivers of the LEB.

In this paper, we examine whether conventional DEM based stream definition approaches, such as 'steepest gradient' (D8) and 'D-infinity' methods or zero-dimensional (0-D) modelling techniques, applied to the SRTM dataset, can accurately define flow paths in a large anastomosing reach of Cooper Creek, the largest river of the LEB.

\section{CASE STUDY}

Cooper Creek drains $306,000 \mathrm{~km}^{2}$ of the 1.14 million $\mathrm{km}^{2}$ area of the LEB. The river originates from the western slopes of the Great Dividing Range in Queensland and flows southwest to Lake Eyre. The study region (Figure 1) is the reach between the confluence of Thompson and Barcoo rivers (upstream limit) and Cullyamura gauging station where the river enters South Australia (downstream limit). The reach comprises a flat floodplain with an area of $18,000 \mathrm{~km}^{2}$ and length of $480 \mathrm{~km}$. The width of the floodplain varies between 10 and 60 kilometres (line B and A respectively in Figure 1) and narrows down to a few hundred meters at Cullyamurra. The elevation at the Currareva gauging station (upstream end of reach) is $130 \mathrm{~m}$ above sea level and decreases gradually to $50 \mathrm{~m}$ at Cullyamura with an average slope of only $2 * 10^{-4}$.

The flow in Cooper Creek is highly seasonal, occurring mainly in the summer, with high interannual variability. On average, once in every six years the water of Cooper Creek reaches the terminus of the catchment at Lake Eyre (Kingsford et al., 1998). Large flood events are associated with the monsoonal rainfall pushing south into the lower reaches with higher amounts of direct rainfall on the floodplain, while the rainfall resulting in moderate flood events is limited to the upper catchments (McMahon et al., 2008).

In Figure 2 the upstream and downstream hydrograph for a medium sized flood in 2004 is illustrated. The volume of upstream inflow for 45 days of flooding was 5370 GL but only $20.3 \%$ of the total flood volume flowed into South Australia at the Cullyamurra gauging station. Knighton and Nanson (1994) estimated that on average only $22 \%$ of water flows into South Australia each year. While the big floods in the region (upstream flow (UF) $>6000 \mathrm{GL}$ ) can inundate a significant area of floodplain, the small (UF $<1500 \mathrm{GL}$ ) to moderate floods (UF: 1500-6000 GL) only partly cover the Cooper Creek floodplain with a greater percentage of the total flow occurring in the anastomosing channels with partial inundation of adjacent floodplains. In Figure 3, the transmission loss of different flood sizes in Cooper Creek is depicted and those of floods with the upstream volume $<5000$ GL varies between 0.5 and 0.95 . 


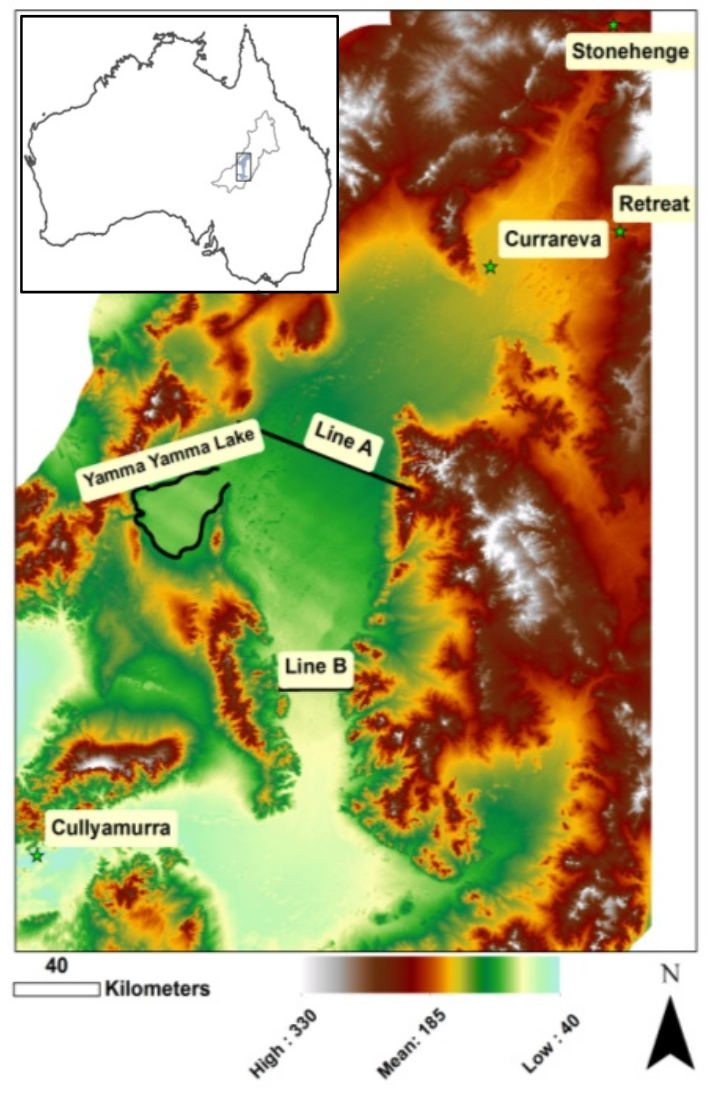

Figure 1: Location of Cooper Creek and its catchment in Australia. DEM and location of gauging stations in the upstream (1968-1988: Currareva, 1988-2000: no data, Stonehenge and Retreat: 2000-2012) and downstream (Cullyamurra:1968-2012)

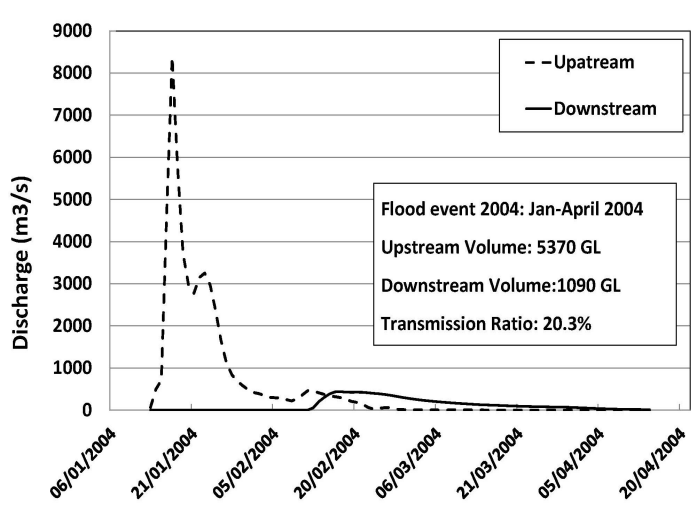

Figure 2: Upstream and downstream hydrograph of Cooper Creek, 2004

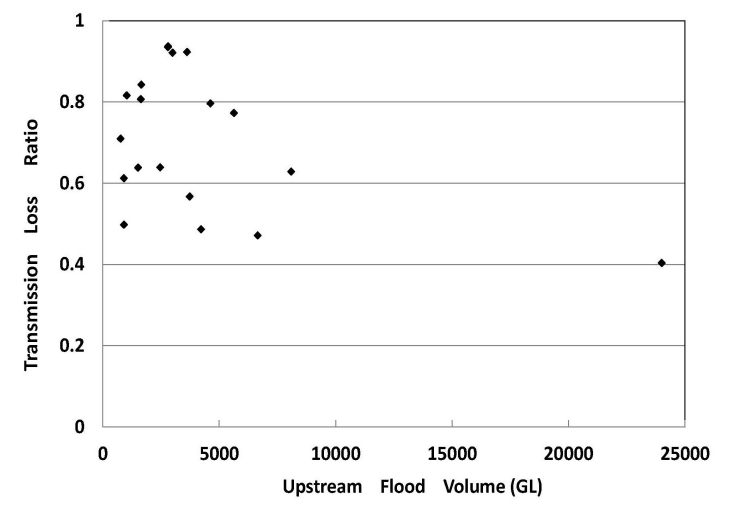

Figure 3: Transmission loss ratio of flood water passing in the upstream to downstream reach of Cooper Creek.

Studies of Cooper Creek and Diamantina River of LEB show that the moderate floods have the highest transmission losses and lowest wave speeds (Knighton and Nanson 1994, 2002; Costelloe et al., 2006). Knighton and Nanson (2002) hypothesised that this pattern was associated with floodwaters being close to bankfull level in the main channels and experiencing higher roughness associated with banktop riparian vegetation. Knighton and Nanson (1994) suggested that the higher transmission ratio (i.e. lower proportional transmission losses) shown by small flood volumes was due to the greater efficiency of flow through a set of primary channels compared to secondary channels that were utilised during larger floods. Costelloe et al. (2006) and McMahon et al. (2008) found that transmission loss and wave speed showed behaviour of a continuum in Diamantina River and hypothesised that a gradual increase in inundated area and flow path length for moderate floods may explain this behaviour rather than flow partitioning between distinctive primary and secondary channel systems. These results indicate that the importance of accurately defining flow paths used by floods with different sizes in the floodplains of Cooper Creek is likely to be critical in modelling these reaches (Costelloe et al., 2006).

\section{METHODOLOGY:}

In order to find flow paths in Cooper Creek, the utility of the SRTM digital elevation dataset is evaluated using DEM based methods; steepest gradient (D8) and D-infinity flow (D $\infty$ ) models. A 0-D model, which maps flooded cells by simply comparing elevation with presumed water level sequentially from an initial upstream cell, is also tried.

The topographic data used to map the streams is SRTM (Shuttle Radar Topography Mission) 1 arc second $(\sim 30 \mathrm{~m})$ DEM collected in February 2000. The DEM represents bare soil topography where the height of vegetated area is corrected by Geoscience Australia using the vegetation information from Landsat images and implementation of interpolating techniques to offset vegetation height. The horizontal positional error is $7.2 \mathrm{~m}$ for $90 \%$ of tested locations in Australia and elevation accuracy is 6.0 and 9.8 meters for the non- 
vegetated and vegetated areas, respectively, for 90\% of errors (Gallant et al., 2010; Rodriguez et al., 2006). However, the elevation for flat bare soils is expected to be more accurate. Sanders (2007) calculated the mean elevation error of $0.02 \mathrm{~m}$ for pasture while this value rises for riparian regions and mountains to 4.08 and $4.69 \mathrm{~m}$ respectively. To investigate the impact of resolution and scale of DEM on resulting flow channels, the DEM cells were aggregated into $240 \mathrm{~m}$ x $240 \mathrm{~m}$ cells. But detailed sensitivity test of the DEM errors against spatial aggregation scale is left for future study.

ArcHydro is an extension of ArcGIS by ESRI designed to conduct watershed delineation using DEM-based flow direction and flow accumulation maps. From any given cell, ArcHydro allows flow only into one of the eight adjacent cells, along the direction of steepest surface gradient, which determines flow direction between cells. In the D-infinity method proposed by Tarboton (1997), the direction of flow follows the same algorithm in the gridded network of DEM but it can have any angle between $0-2 \pi$ and the flow can be directed into two of eight adjacent cells and the proportion of flow is directly related to the angular proximity of final flow direction to the two adjacent cells. The results have been processed using TAUDEM (Terrain Analysis Using DEM) software developed in the Utah State University, USA (http:/hydrology.uwrl.usu.edu /taudem/taudem5.0/index.html).

In addition, 0-D inundation model (Woodhead et al., 2007) was applied to find the channels in the study reach. The results of this approach have been satisfactory in mapping the flow patterns of some floodplains (Bates and De Roo, 2000). Constant water levels in the upstream Thompson and Barcoo Rivers were used as boundary conditions. Water in each pixel can flow to the eight adjacent cells provided that the water level is higher than the elevation of the cells and the new wetted cells are marked as inundated. In the case of no transmission loss, the water level is decreased downstream according to the gradient of thalweg in the river or floodplain slope. This process is repeated iteratively, propagating inundation downstream:

\section{Downstream Cell Height $=$ Upstream Cell Height - Gradient x Cell Distance}

In order to simulate the attenuation of the flow pulse and transmission losses, a reduction rate in the water height was also applied over specified sub-reaches. The main parameters that the user can control in the 0-D model are the water height of Barcoo and Thompson Rivers as boundary conditions and the reduction rate of water level in the Cooper Creek. In order to model floods with different magnitudes, values of 3, 5 and $7 \mathrm{~m}$ for the water depth in the upstream boundaries were used to represent small, medium and large floods respectively. Furthermore, the reduction rate of water level was applied in the model by assumptions of no transmission loss and a transmission loss with the result of $75 \%$ reduction in water depth. For the "no transmission loss" scenario the water level was only reduced according to the slope of elevation in the thalweg of upstream rivers and Cooper Creek floodplain. Regarding the extremely flat topography of Cooper Creek with a low slope $\left(2 \times 10^{-4}\right)$, the floodplain slope was estimated by a linear regression performed on three separate parts. For the scenario of $75 \%$ transmission loss in water depth an additional reduction in the water level was added to the downward slope represented by the thalweg and applied in the model. The three sub-reaches were chosen to represent significant changes in the width of floodplain, so that where the width increases the declining slope of water depth due to transmission loss was considered to be higher.

\section{RESULTS AND DISCUSSION:}

\subsection{DEM based stream definition approaches}

The results of mapping stream lines using the D $\infty$ method are depicted in Figure 4a with the main streams mapped by considering a minimum $8 \times 10^{6}$ upstream pixels covering $7200 \mathrm{~km}^{2}$ for each major channel. While the $\mathrm{D} \infty$ method has been demonstrated to have the potential of mapping multiple flow directions (Tarboton 1997), here the simulated networks depicts a dendritic structure (Figure 4a in dark blue) and an anastomosing network is not modelled. In order to determine if the method could map anastomosing patterns over smaller reaches, streams are simulated by considering $10^{6}$ upstream pixels (covering minimum $900 \mathrm{~km}^{2}$ ) and results are overlaid in light blue in Figure 4a. The denser channel network still maintains a dendritic structure. The number of anastomosing loops (i.e. divergent rather than convergent confluences) produced by TAUDEM is negligible in comparison to those observed in satellite images of Cooper Creek and only produced at very small scales. The anastomosis replicated in Figure $5 \mathrm{c}$ for a small area $(6.75 \mathrm{~km} \mathrm{x} 6.75 \mathrm{~km})$ is an example of TAUDEM producing anastomosing channels at some locations but these are not significant in comparison to actual stream network even at this small scale.

The network generated by ArcHydro using the D8 method was not able to reproduce the anastomosing patterns of Cooper Creek either. In Figure $4 \mathrm{~b}$ the results of channel mapping in ArcHydro and TAUDEM using the 30-m DEM are overlaid on the observed channels from Landsat 7 ETM+ (bands 2 (Red), 4 (Green), 
and 7 (Blue)) for the February 2000 flood event near Currareva. The patterns produced by both methods have minimal difference in channels but the dendritic structure replicated is not simulating the anastomosing pattern of the flood event. While the D $\infty$ method basically allows bifurcations of channels and simulation of occasional anastomosing patterns, the D8 method fundamentally does not simulate the anastomosing patterns at any scale and only produces dendritic patterns.

One of the other shortcomings of DEM based methods for low gradient rivers is the sensitivity of DEM resolution on the mapping of channels. In order to check the sensitivity of channel mapping to the spatial resolution of DEM, the channels were mapped using 30-m pixels in TAUDEM and the procedure was repeated for a $240 \mathrm{~m}$ resolution SRTM (see Figure 4c for a region near Currareva). In the particularly flat parts of the floodplain the aggregation of elevation data has resulted in different flow paths for 30 and $240 \mathrm{~m}$ datasets while the results for the regions where the slopes are steeper show a better match. This is evident in the adjacent hills to the floodplain in the bottom right corner of Figure 4c. In summary, DEM-based approaches such as D8 and D methods are only based on topographic characteristics and can be implemented successfully to define streams in the catchments with steep slopes to force water move in downward gradients. But when topographic relief is not high enough as in extremely flat floodplains, water depth and slight difference in elevation around the flow front determine the stream network. In addition, DEM-based methods are highly sensitive to the resolution of DEM as depicted in Figures 4b and 4c.

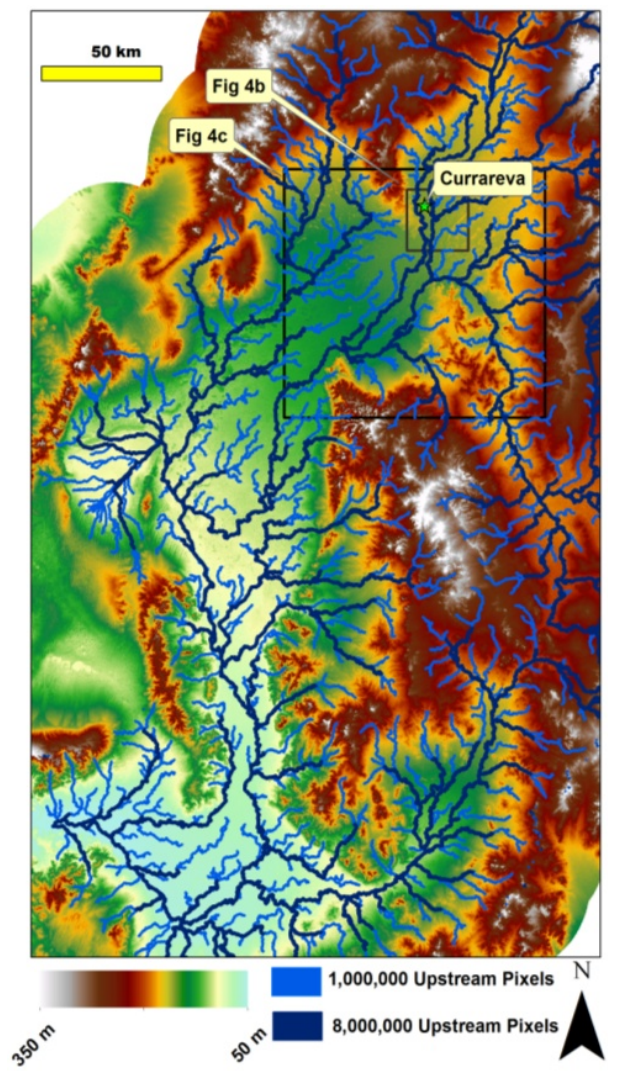

a

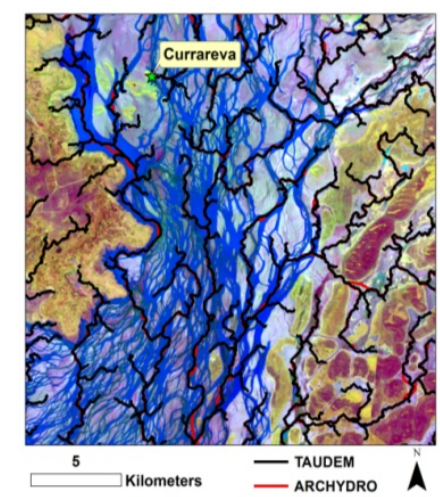

b

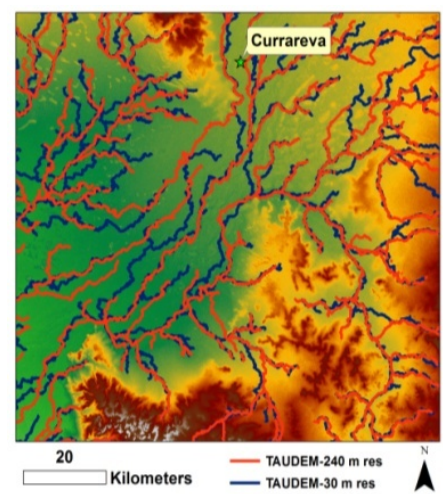

Figure 4(a) Stream channels generated by TAUDEM in the Cooper Creek in 30-m resolution $\left(10^{6}\right.$ (light blue) and $8 \times 10^{6}$ (dark blue) upstream pixels for each river); (b) Stream channels generated by ArcHydro (red lines) and TAUDEM (black lines) in 30$\mathrm{m}$ DEM on the satelliteobserved flow patterns for the flood event of February 2000, Landsat $7 \mathrm{ETM}+$ (bands 2 (Red),4 (Green), and 7 (Blue)) upstream of Currareva; (c) Stream channels in 30-m and 240-m DEM for a region in Cooper Creek near Currareva.

\subsection{Zero Dimensional Model}

The results of running the 0-D model are illustrated in Figure 5. In Figure 5a, a boundary condition of $3 \mathrm{~m}$ in the upstream rivers was considered to represent a small flood with no transmission loss. The resulting inundation area covers only a small part of upstream floodplain and the flow is terminated by small-scale topographic features in the floodplain. The mapping result is contrary to the observed record where small floods can flow through the reach in the primary channels with a transmission loss mainly in the range of 60$85 \%$ (Figure 3). In the second simulation, the model was run with the water depth of 5 meters to represent medium floods with no transmission loss (Figure $5 \mathrm{~b}$ ). The resulting mapped inundation area covers vast areas of the floodplain and does not identify anastomosing channels within the floodplain. The same boundary condition was applied in the third simulation with $75 \%$ reduction in water depth from upstream to 
downstream to account for transmission loss (Figure 5c). In that case, the mapped inundation area is still covering large areas of floodplain without replication of anastomosing channels but the reduction rate of depth due to transmission loss has resulted in the mid-reach termination of flow.
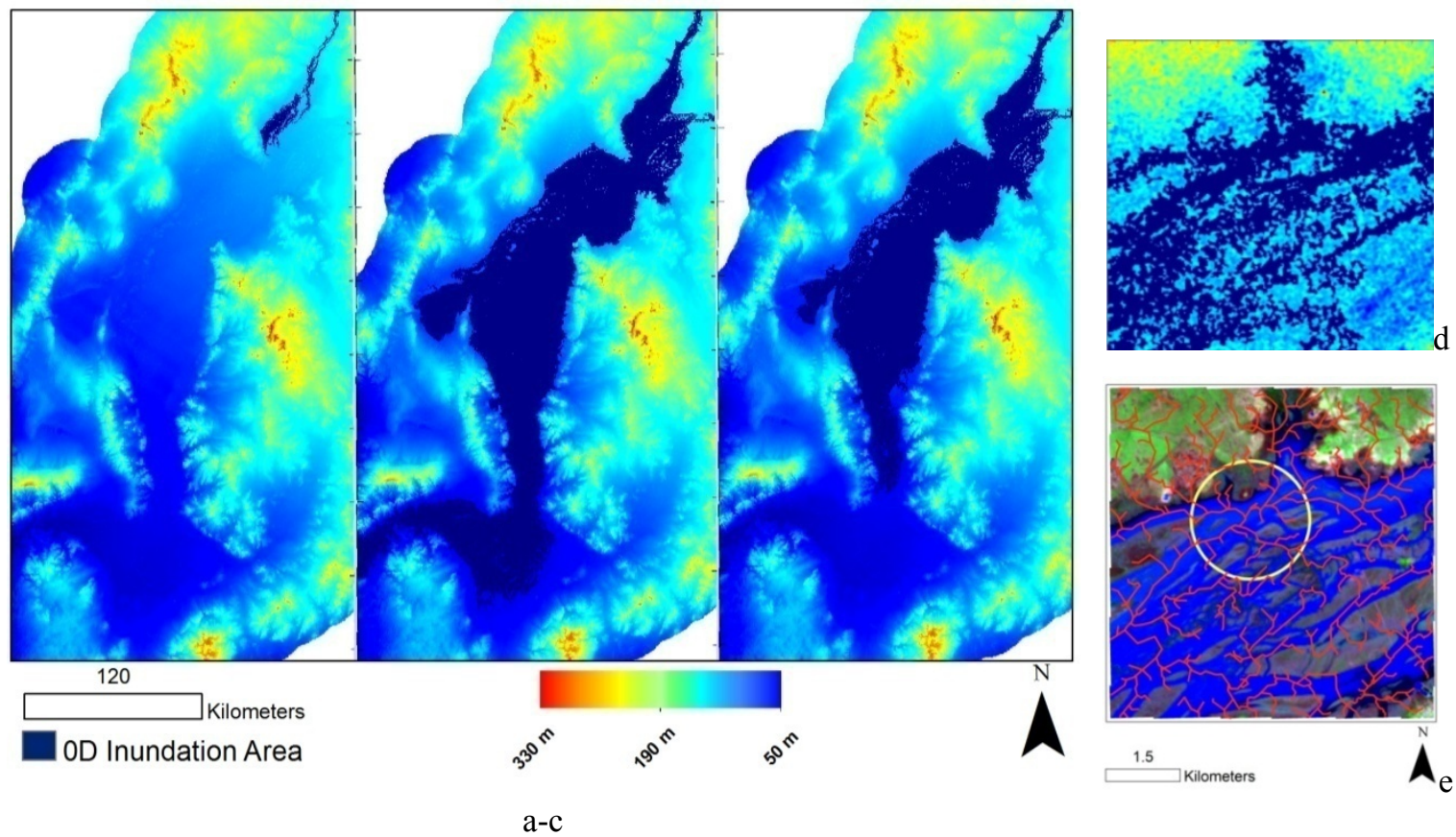

Figure 5(a) Flood mapping of Cooper Creek (dark blue) for a small flood with no transmission loss; (b)

Medium flood with no transmission loss; (c) Medium flood with 75\% reduction of water depth as transmission loss; (d) Inundation map of a small region in Thompson River downstream of Longreach $(6.75$ x $6.75 \mathrm{~km}$ ) modelled by 0-D model (dark blue); (e) Observed coverage for the 1990 flood event, image of Landsat 5 TM (bands 2 (Red), 4 (Green), and 7 (Blue)) and overlaying TAUDEM stream network with only one replication of bifurcation in anastomosing rivers (center of yellow circle).

The results demonstrate that the application of the 0-D model to map the anastomosing channels faces considerable drawbacks. Firstly, the extent of flooding is very sensitive to the upstream boundary condition and switches from insignificant flooding at low water levels (i.e. can't simulate low flow patterns) to total flooding above some threshold (i.e. can't simulate flow patterns from medium floods either). Secondly, the use of a reducing water gradient to simulate the effects of transmission losses is not effective either, as it still results in total flooding of the floodplain in the upper part of the reach and then flooding terminates midreach. One of the main reasons of failure in mapping the small floods in 0-D models is that the rule of conservation of water is violated and the water stops behind any obstacle which is higher than the water level. In reality, water can accumulate behind topographic obstacles so that the elevation of water increases to the level that it surpasses barriers. Scale is also an important factor in the accuracy of 0-D model results. As the water is not conserved in the 0-D models, the effect of widening and narrowing of floodplain, or existence of any topographic changes, cannot be modelled in an appropriate way at large scale. Bates and Roo (2001) compared the results of a 0-D model of free surface to LISFLOOD-FP (a hybrid1D-2D raster based diffusion wave hydrodynamic model) and HEC-RAS (a one dimensional kinematic wave model) models in the River Meuse in Netherland. The results for a 7-km reach were comparable for the three methods with correct prediction of $83.7 \%$ of inundated area for the 0 -D model in comparison to $85.5 \%$ of accuracy for HEC-RAS and $84.9 \%$ of LISFLOOD. The accuracy of inundation area mapped by the 0-D model reduced to $69.5 \%$ for $35 \mathrm{~km}$ of Meuse River while the accuracy of HEC-RAS and LISFLOOD remained high at $81.6 \%$ and $80.6 \%$ respectively. Therefore, the scale of region in the zero dimensional modelling of inundation mapping plays an important role in the accuracy of results. In Figure $5 \mathrm{~d}$ the planar approximation of water level has been implemented for a small anastomosing reach with the dimension of $6.75 \times 6.75 \mathrm{~km}$ in the Thompson River (one of the major tributaries of Cooper Creek), where the width of floodplain is $8 \mathrm{~km}$. By comparing the results of 0-D model with the observed inundation map for the 1990 flood event (Landsat 5 TM, bands 2(Red), 4 (Green), and 7 (Blue)), an accuracy of 73\% is achieved. The stream network defined by TAUDEM is also overlaid on the observed inundation area in Figure 5c. Here, the bifurcation pattern of anastomosing river has only been replicated in only one point of the reach (shown by 
yellow circle) and the dendritic form of channels is modelled even at this small scale area, which is not following the observed anastomosing pattern of channels in this reach.

\section{CONCLUSION AND RECOMMENDATIONS}

This paper has tested two methods of mapping flow paths in an anastomosing river with large and extremely flat floodplains. The DEM based stream definition methods (D8 and D-infinity) that utilise only topographic data were tested in Cooper Creek but failed to simulate the anastomosing channel patterns that are the distinguishing feature of Cooper Creek. Therefore, we conclude that the water height of the flow pulse should be also considered when mapping the flow paths. This demonstrates some of the fundamental flaws in the flow path mapping by DEM-based schemes such as ArcHydro and TAUDEM. In the second approach, a 0-D model was tested in Cooper Creek by overlaying a water surface onto the DEM to find the flow paths. For large extent, this method did not reproduce observed flooding patterns, but the results at a small sub-area indicated that the 0 -D method could reproduce complex flow channels at small scales (e.g. reaches $<10 \mathrm{~km}$ in length). The failure is attributed to the violation of mass conservation in the 0-D model. Therefore, implementation of hydrodynamic models that conserve water and momentum is required to simulate realistic movement of water and transmission losses in anastomosing rivers.

In addition to the need of hydrodynamic models, remotely sensed optical (e.g. Landsat and MODIS images) and radar altimetry data (e.g. TOPEX/Poseidon, Envisat, Jason 1 and Jason 2) can provide a promising opportunity to investigate the more accurate behaviour of large anastomosing rivers. Our results indicate that successful simulation of flow paths in large and arid floodplain rivers is a considerable challenge, even with the aid of remote sensing data.

\section{REFERENCES}

Bates, P. D., \& De Roo, A. P. J. (2000). A simple raster-based model for flood inundation simulation. Journal of Hydrology, 236(1), 54-77.

Costelloe, J. F., Grayson, R. B., Argent, R. M., \& McMahon, T. A. (2003). Modelling the flow regime of an arid zone floodplain river, Diamantina River, Australia. Environmental Modelling \& Software, 18(8), 693703.

Dowling, T. I., Brooks, M., \& Read, A. M. (2011, October). Continental hydrologic assessment using the 1 second (30m) resolution Shuttle Radar Topographic Mission DEM of Australia. In MSSANZ 2011 Perth.

Gallant, J.C., T.I. Dowling, A.M. Read, N. Wilson, P. Tickle (2010). 1 Second SRTM Level 2 Derived Digital Elevation Model v1.0. http:/www.ga.gov.au/meta/ANZCW0703013355.html

Kingsford, R. T., Boulton, A. J., \& Puckridge, J. T. (1998). Challenges in managing dryland rivers crossing political boundaries: lessons from Cooper Creek and the Paroo River, central Australia. Aquatic Conservation: Marine and Freshwater Ecosystems, 8(3), 361-378.

Knighton, A. D., \& Nanson, G. C. (1994). Flow transmission along an arid zone anastomosing river, Cooper Creek, Australia. Hydrological Processes, 8(2), 137-154.

Knighton, A. D., \& Nanson, G. C. (1997). Distinctiveness, diversity and uniqueness in arid zone river systems. Arid Zone Geomorphology: Process, Form and Change in Drylands, Thomas DSG (ed). 2nd Edition, John Wiley \& Sons, 185-203.

Knighton, A. D., \& Nanson, G. C. (2002). Inbank and overbank velocity conditions in an arid zone anastomosing river. Hydrological Processes, 16(9), 1771-1791.

Makaske, B. (2001). Anastomosing rivers: a review of their classification, origin and sedimentary products. Earth-Science Reviews, 53(3), 149-196.

McMahon, T. A., Murphy, R. E., Peel, M. C., Costelloe, J. F., \& Chiew, F. H. (2008). Understanding the surface hydrology of the Lake Eyre Basin: part 2-streamflow. Journal of Arid Environments, 72(10), 1869-1886.

Rodriguez, E., Morris, C. S., \& Belz, J. E. (2006). A global assessment of the SRTM performance. Photogrammetric Engineering and Remote Sensing, 72(3), 249-260.

Sanders, B. F. (2007). Evaluation of on-line DEMs for flood inundation modeling. Advances in Water Resources, 30(8), 1831-1843.

Schumann, R. R. (1989). Morphology of Red Creek, Wyoming, an arid region anastomosing channel system. Earth Surface Processes and Landforms, 14(4), 277-288.

Tarboton, D. G. (1997). A new method for the determination of flow directions and upslope areas in grid digital elevation models. Water resources research, 33(2), 309-319.

Woodhead, S., Asselman, N., Zech, Y., Soares-Frazao, S., Bates, P., \& Kortenhaus, A. (2007). Evaluation of inundation models. FLOODsite Project Report T08-07-01. 